\title{
Alterations in Gonads and Liver Tissue in Two Neotropical Anuran Species Commonly Occurring in Rice Fields Crops
}

\author{
Lucila M. Curi $\mathbb{D}$ - Paola M. Peltzer • \\ Maximiliano A. Attademo • Rafael C. Lajmanovich
}

Received: 21 January 2021 / Accepted: 29 April 2021

(C) The Author(s), under exclusive licence to Springer Nature Switzerland AG 2021

\begin{abstract}
Amphibians find a suitable habitat in rice agroecosystems, but their viability is affected by the sublethal effects of agrochemicals. Animal condition, external morphology, and liver and male gonad tissue histology were examined on Lysapsus limellum and Rhinella bergi, common species that occurs in rice fields (RF) and reference sites (RS) from Santa Fe and Chaco provinces, Argentina, respectively. Animal condition factor showed no significant differences between environments in either species. Males of both species from RF showed asymmetrical testis size. A higher proportion of cysts with early spermatogenesis cell stages were observed in RF specimens than in RS individuals. The proportion of tubules with free spermatozoa differed between environments for L. limellum. Bidder organ presented vacuoles, atretic follicles, and pigmentary cells in $R$. bergi from Chaco RF. Liver tissues of both species from RF exhibited sinusoid enlargement, hypervascularization, hepatocyte vacuolization, and dilated blood vessels. $R$. bergi had a higher number of hepatic melanomacrophages in RF than in RS. The histological biomarker was more sensitive than the morphological one to evaluate chronic pesticide exposure
\end{abstract}

L. M. Curi

Instituto de Ictiología del Nordeste (INICNE), Facultad de Ciencias Veterinarias, Universidad Nacional del Nordeste, Corrientes, Argentina

L. M. Curi $(\bowtie) \cdot$ P. M. Peltzer · M. A. Attademo •

R. C. Lajmanovich

Consejo Nacional de Investigaciones Científicas y Técnicas

(CONICET), Buenos Aires, Argentina using anuran non-target organs (liver, gonads) and Bidder organ. The potential effect of those alterations on the reproductive performance of anurans that commonly occur in agroecosystems needs further research.

Keywords Agroecosystems · Amphibians · Histological testis alteration $\cdot$ Hepatic melanomacrophages

\section{Introduction}

Intensive land uses, such as agriculture, modify the ecosystems and cause loss of wild habitats, nutrient runoff, greenhouse gas emissions, and contamination by pesticides in humans and non-target organisms (Power \& Jetz, 2019). Rice (Oryza sativa L.) is one of the most extensively cultivated cereals in the world, occupying more than $11 \%$ of arable land (Kole et al., 2010). In Argentina, more than $50 \%$ of the land is cultivated with soybean and rice, with rice production has reached 1.1 million tons in the 2018/2019 crop season and covering 190,800 hectares (SIIA, 2019).

e-mail: lucilacuri@gmail.com

P. M. Peltzer • M. A. Attademo - R. C. Lajmanovich Laboratorio de Ecotoxicología, Facultad de Bioquímica y Ciencias Biológicas (FBCB), Universidad Nacional del Litoral (UNL), Santa Fe, Argentina 
This rice agroecosystem provides temporary food and niche resources for many vertebrates, which are exposed to several pesticides (Attademo, Lorenzón, et al., 2018a; Lorenzón et al., 2020). The main herbicides used for rice crops are bentazone, molinate, propanil, clomazone, 2,4-D Amina, and glyphosate (Quayle et al., 2006; Terrado et al., 2007), whereas dimethoate, parathion, imidacloprid, and carbofuran are the most widely used insecticides (Parsons et al., 2016). Pesticides and contaminants of emerging concern accumulate in aquatic environments, negatively affecting ecology, physiology, ethology, and metabolism; therefore, they are an important driver of global amphibian decline (EgeaSerrano et al., 2012; Tamschick et al., 2016). Ecotoxicological studies provide evidence of the adverse effects of agrochemicals worldwide (Relyea, 2005; Sievers et al., 2019).

Amphibians play important roles, such as pest biological control in agricultural systems (Attademo et al., 2005; Khatiwada et al., 2016) and energy flow from aquatic to terrestrial habitats (Sánchez-Hernandez, 2020). Anuran species were found to differ in their sensibility within the field crops (Pyron, 2018). Agrochemicals cause reproductive dysfunction and abnormal development in anurans via interference with the endocrine system (Trudeau et al., 2020). In addition, evidence of endocrine disruptions in other vertebrates exposed to agrochemicals was investigated (Matthiessen et al., 2018; Mnif et al., 2011).

Gonadal dysgenesis and morphological alterations, presence of intersex gonads, and testicular oocytes have been frequently reported worldwide in frogs (Hayes et al. 2006a, b; McCoy et al., 2017). Laboratory experiments demonstrated deleterious effects of glyphosate and atrazine exposure on amphibian reproduction (Hayes et al., 2010; Hayes, Stuart, et al., 2006a; Howe et al., 2004; Tavera-Mendoza et al., 2002). The majority of studies that reported the prevalence of intersex are referred to anuran species from North America (reviewed by Abdel-moneim et al., 2015). However, a causal relationship between environmental concentrations of endocrine disruptors and the prevalence and severity of intersex on wildlife individuals was unable to establish (Abdel-moneim et al., 2015). In South America, the effects of agrochemicals on anuran reproduction have been scarcely studied at the field scale, and few reports suggested morphological or histological gonad abnormalities (Rojas-Hucks et al., 2019; Sánchez et al., 2014). Further evidence regarding gonad histology, endocrine disruption, and effects on reproduction is needed to characterize the biological risk of anurans exposed to compounds with endocrine effect (Cevasco et al., 2008; Matthiessen et al., 2018).

On the other hand, the liver is widely used in ecotoxicological studies in different vertebrates due to its important role in biotransformation processes of xenobiotics, which involves both hepatocytes and Kupffer cells (also called melanomacrophages/MMs) through enzymatic and nonenzymatic mechanisms (Fenoglio et al., 2005; Loumbourdis, 2007). MMs are pigmented cells located in hematopoietic organs, such as the liver in frogs, which participate in immunological response and detoxification of pollutants (Bach et al., 2018; Steinel \& Bolnick, 2017). The abundance of MMs in the liver parenchyma after anuran exposure to pesticides was recorded in laboratory assays (Bernabó et al., 2014; Cakici, 2015; Curi et al., 2019; De Oliveira et al., 2016); however, few studies reported similar effects on frogs occurring in agroecosystems (Huespe et al., 2017; Jantawongsri et al., 2015).

In the present study, adults of two anuran species (Lysapsus limellum and Rhinella bergi) with different ecological characteristics (reproductive mode, microhabitat use) inhabiting rice fields were selected as bioindicators. Three hypotheses were tested: (a) the morphological parameters measured in adults (length, weight, and animal condition factor) differ between rice and reference sites, (b) the morpho-histology of gonads (testicular volume, spermatogenic cyst proportion, and quantity of free spermatozoa) is altered due to chronic exposure to agrochemicals in rice fields, and (c) MMs increase in the liver of anurans from rice fields.

\section{Materials and Methods}

\subsection{Study Sites}

Anuran surveys were carried out in two rice fields (RF1 and RF2); the natural environments where these anurans occur were used as reference sites (RS1 and RS2) in the central-eastern of Argentina (Fig. 1). RS1 is a wetland site associated with the Paraná River, near forest fragments in the locality of Garay (Santa Fe province, $31^{\circ}$ $\left.10^{\prime} 21.1^{\prime \prime} \mathrm{S}, 60^{\circ} 15^{\prime} 31.73^{\prime \prime} \mathrm{W}, 700 \mathrm{ha}\right)$. This area has no agricultural activities (Attademo et al., 2011; Huespe et al., 2017). The RF1 was a rice (Oryza sativa) cropland situated in the locality of San Javier (Santa Fe province, 


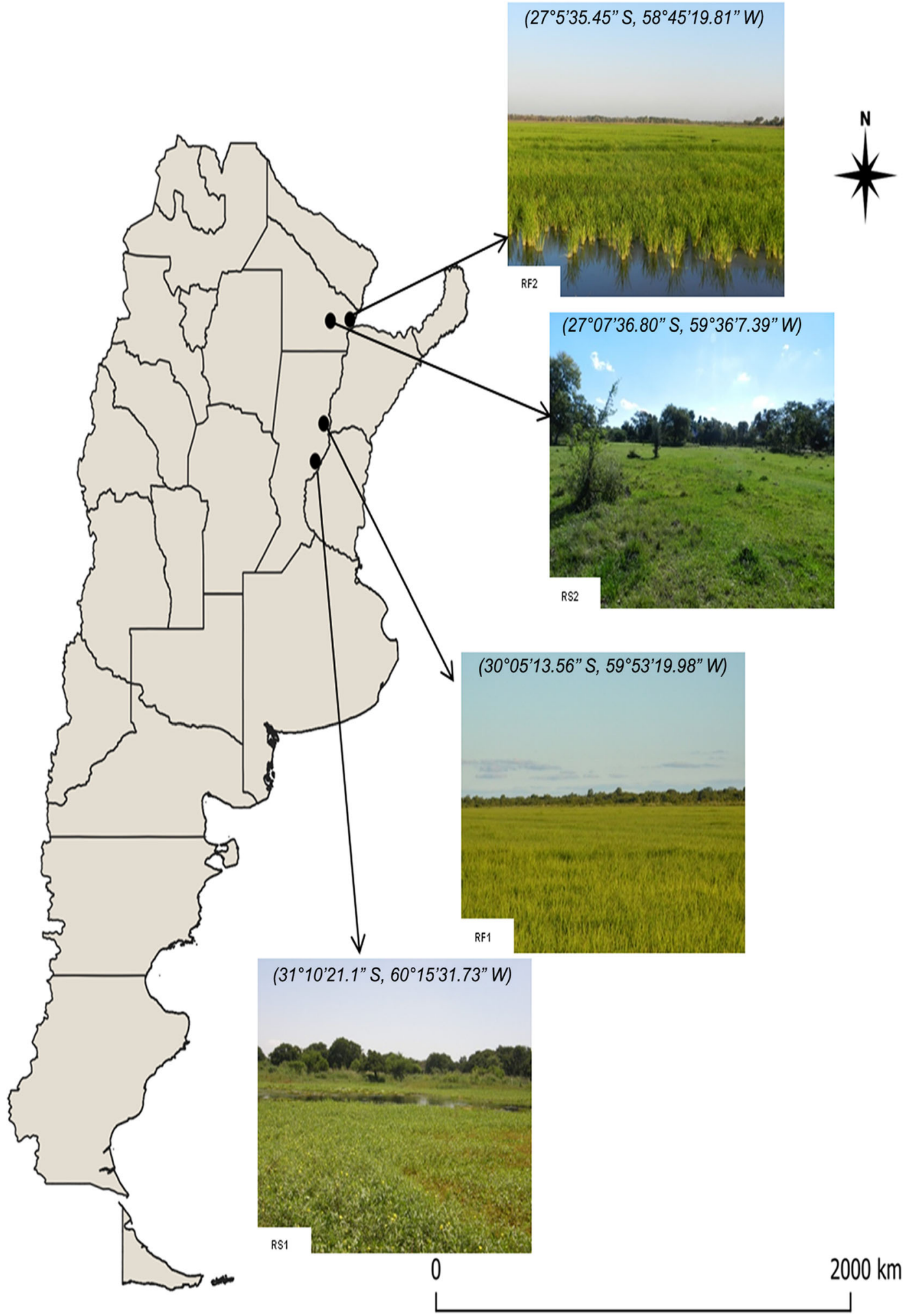

Fig. 1 Location and general view of sampling sites in Santa Fe (RF1 and RS1) and Chaco (RF2 and RS2) provinces, Argentina. References: RF1, rice field located in San Javier department; RS1, reference site located in Garay department; RF2, rice field located in Bermejo department; RS2, reference site situated in Presidencia de la Plaza department 
$30^{\circ} 05^{\prime} 13.56^{\prime \prime} \mathrm{S}, 59^{\circ} 53^{\prime} 19.98^{\prime \prime} \mathrm{W}, 287$ ha). The distance between the RF1 and RS1 is approximately $50 \mathrm{~km}$. Rice fields are surrounded by several forest fragments with native vegetation of the Paraná River Delta and islands and Espinal ecoregions. The average annual temperature ranges between 15 and $20{ }^{\circ} \mathrm{C}$ (Apodaca et al., 2015), and the rainy season is from October to March.

The other two sites, RF2 and RS2, were located in the Humid Chaco ecoregion. These two sites were characterized by a warm subtropical climate with a mean annual temperature of $26^{\circ} \mathrm{C}$ and rains concentrated in summer months (Burkart et al., 1999). RS2 was located in the Presidencia de la Plaza department (Chaco province, $27^{\circ} 07^{\prime} 36.80^{\prime \prime} \mathrm{S}, 59^{\circ} 36^{\prime} 7.39^{\prime \prime} \mathrm{W}, 300 \mathrm{ha}$ ). This site presented native vegetation where agricultural activities or direct agrochemical runoff is far away (10 $\mathrm{km}$ ); non-intensive cattle settlements are performed in adjacent areas. RF2 was a rice field located in the locality of Bermejo (Chaco province, $27^{\circ} 5^{\prime} 35.45^{\prime \prime} \mathrm{S}$, $58^{\circ} 45^{\prime} 19.81^{\prime \prime} \mathrm{W},>500 \mathrm{ha}$ ). The distance between RF2 and RS2 is approximately $90 \mathrm{~km}$.

\subsection{Selection of Anuran Species}

Lysapsus limellum (Amphibia, Anura, Hylidae) was selected because it is frequently found in the rice field (Duré et al., 2008), and it was previously used as a bioindicator in another ecotoxicological study (Attademo et al., 2015). This is a small-sized frog species that can reach $20 \mathrm{~mm}$ of snout-vent length (SVL) at adult stages and has an aquatic lifestyle. It inhabits permanent or semi-permanent water bodies with abundant submerged or floating vegetation (Zaracho et al., 2011). It is found in contact with water or associated with aquatic vegetation (Attademo et al., 2015; Duré et al., 2008). In Argentina, it is widely distributed in the Chaco, Espinal, and Paranaense ecoregions and is categorized as "not threatened" (Vaira et al., 2012; Zaracho et al., 2011). It feeds on dipterans, orthoptera, arachnids, and fish (Duré \& Kehr, 2001).

Rhinella bergi (Amphibia, Anura, Bufonidae) was also selected because it frequently occurs on secondary unpaved roads crossing rice crops. Other similar bufonids species (Rhinella arenarum, R. fernandezae, and $R$. dypticha) have been used as bioindicators in laboratory and field studies (Lajmanovich et al., 2004, 2019; Sánchez et al., 2014). This frog can reach $50 \mathrm{~mm}$ in total length, has a terrestrial lifestyle (burrowing habitats), and is distributed throughout the Chaco and Espinal ecoregions in Argentina (Zaracho et al., 2011). It is categorized as "not threatened" (Vaira et al., 2012). It is insectivorous, feeding mainly on ants and beetles (Duré et al., 2008).

\subsection{Anuran Field Sampling}

Both L. limellum and Rhinella bergi were sampled in two environment types (RF and RS), the former in Santa $\mathrm{Fe}$ province and the latter in Chaco province. Both species were abundant in each rice crop field (Attademo, Lorenzón, et al., 2018a; Duré et al., 2008). Sampling was performed during two consecutive annual periods (2015-2016 and 2016-2017) simultaneously with the anuran breeding season (Curi et al., 2014) between November and March. The samplings were made between 19:00 and 01:00 once a month accounting $n=10$ sampling dates in each survey site during the entire studied period. The rice period covers the entire crop cycle, from sowing to harvest. Visual and auditory encounter techniques (Crump \& Scott, 2001; Zimmerman, 2001) were used during day and night surveys (a minimum of $6 \mathrm{~h}$ a day). A total area of 80.06 ha was surveyed in each environment. We captured the individuals by hand, collecting a maximum number of 10 adult males per species from each site on each sampling date. Only individuals with evident secondary sexual characters or calling males were captured (Sánchez et al., 2014). Collection permissions were granted by the Wildlife and Natural Areas department of Chaco Province and the Environment Ministry of Santa Fe Province (Nº2101-0018519-1).

2.4 Measurements of External Morphology and Organ Dissection in Males

A total of $n=26$ and 13 L. limellum individuals were collected from RF1 and RS1, respectively, whereas $n=24$ and $13 R$. bergi individuals were collected from RF2 and RS2, respectively. They were anesthetized individually by immersion in a buffered solution of $0.1 \%$ tricaine methanesulfonate (MS-222), following the guidelines of ASIH (2004) and with the approval of the Committee of Bioethics of the Facultad de Bioquímica y Ciencias Biológicas of the Universidad Nacional del Litoral (Santa Fe, Argentina; Res. CD. $\mathrm{N}^{\circ} 388 / 06$ ). Individuals were weighed (WE) using a digital balance $(0.01 \mathrm{~g}$ precision) and their snout-vent 
length (SVL) was measured with digital calipers (0.01 $\mathrm{mm}$ precision). Animal body condition factor (CF) was calculated using the formula of Bagenal and Tesch (1978) as follows: $\mathrm{CF}=[\mathrm{WE}(\mathrm{g}) / \mathrm{SVL}(\mathrm{mm})]^{3}$ *100]. Each individual was dissected along the midventral line (longitudinal incision), and digestive organs (stomach, intestine) were removed to photograph reproductive organs under a stereoscopic magnifying glass. Subsequently, the reproductive organs were fixed in Bouin solution (24 h) and preserved in alcohol (70\%). The specimens were numbered and deposited in the Universidad Nacional del Nordeste (UNNE) Herpetological Collection (Corrientes, Argentina).

\subsection{Morphological and Histological Gonadal}

Assessment

\subsubsection{Assessment of External Gonadal Morphology}

The length and width of the testes of both species were measured before the Bouin fixation using digital calipers $(0.001 \mathrm{~mm})$ under a binocular stereomicroscope (Leica Ez4W). Testicular volume (TV) was calculated with the spheroid formula (Dunham, 1981). Additionally, the external morphology of testes was examined for scored abnormalities (Coady et al., 2005; Hecker et al., 2006; Sánchez et al., 2014).

\subsubsection{Histological Assessment of Male Gonads}

The urogenital system (testes and kidneys in L. limellum, testes + Bidder organs $(\mathrm{BO})$, and kidneys in $R$. bergi) was removed from $n=6$ male individuals from RF1-2 and RS1-2 for histological procedures. The tissues were dehydrated in increasing ethanol concentrations, cleared in butyl-paraffin, and embedded in paraffin. Transverse sections of the central regions of gonads were cut $(4-5 \mu \mathrm{M})$ with a rotary microtome and stained with hematoxylin-eosin (H-E) and Gomory Trichrome (GT). Sections were analyzed and photographed with a digital camera (Leica LCC50HD) that was mounted on a light microscope (Leica DM500).

The testicular cells present in the seminiferous tubules were classified as spermatogonia ( $\mathrm{Sg}$ ), primary spermatocytes (ISc), secondary spermatocytes (IISc), spermatids at different stages of maturation (Sp), spermatozoa bound to Sertoli cells (Sz), or free spermatozoa
(FSz) (De Souza Santos \& De Oliveira, 2008; Ferreira et al., 2008). In each testis, 10 seminiferous tubules of a medial section of the right gonad were examined (Sánchez et al., 2014). The number of cysts with spermatogenic cells at early stages (CES) ( $\mathrm{Sg}$, ISc, and IISc) and with spermatogenic cells at late stages (CLS) (Sp, $\mathrm{Sz}$ ) were counted (adapted from Tsai et al., 2005). The number of spermatozoa in the lumen of the seminiferous tubules was estimated and converted to score numbers between zero and three, with zero corresponding to seminiferous tubules with no spermatozoa and three representing those with the highest number of spermatozoa (Gyllenhammar et al., 2009).

In addition, testicular anomalies were identified in histological sections under a light microscope (Kloas et al., 2009; McCoy et al., 2017). For L. limellum, the intensity of external gonad pigmentation was categorized following the classification of Franco-Belussi et al. (2017), as 0 (absence of pigment cells on organ surface), 1 (a few scattered of pigment cells), 2 (a large number of pigment cells), and 3 (a massive amount of pigment cells).

In $R$. bergi, the $\mathrm{BO}$ was histologically characterized using specific literature such as Scaia et al. (2011), Piprek et al. (2014), and Freitas et al. (2015).

\subsection{Liver Histological Evaluation}

The liver from six individuals per site (RF1-2 and RS12) was used for the histological procedures. Transverse histological sections $(4-5 \mu \mathrm{M})$ of the central region of the liver were cut with a rotary microtome and stained with H-E and GT. They were observed and photographed under a light microscope (Leica DM500) equipped with a digital camera (Leica LCC50HD).

Six photographs $(\times 40$ field of magnification $)$ of nonconsecutive liver sections of each individual were observed and digitized (Chai et al., 2017). The number of MMs in each section was quantified using Image J software (adapted from De Oliveira et al., 2016 and Bach et al., 2018). Furthermore, the same histological sections were analyzed under a light microscope to identify the presence of hypervascularization (congestion), sinusoid enlargement, blood vessel dilation, hepatocyte vacuolation, or necrosis, among others (Cakici, 2015; Sayed \& Younes, 2017). One person made all histological assessments. 


\subsection{Statistical Analyses}

Before each statistical analysis, normality and homogeneity of variances were tested using the KolmogorovSmirnov and Levene tests, respectively (Zar, 1999). A one-way analysis of variance (ANOVA (F)) was used to compare SVL, CF, and WE of individuals between sites. TV did not meet the assumptions of parametric tests; therefore, it was natural-log transformed. Then, an ANCOVA (F) was used with the SVL as a covariate. The mean number of cysts with CES (Sg, ISc, and IISc) and cysts with CLS (Sp, Sz) was compared between sites using a KW test due to the non-parametric nature of the variables. Additionally, a chi-square $\left({ }^{2}\right)$ test was used to check for significant differences in the proportion of seminiferous tubules with abundant, moderate, small, and no amount of free spermatozoa in the lumen between sites. Thus, number of MMs in liver sections was compared between sites using a KW test. All the statistical analyses were performed with Infostat $/ \mathrm{P}$ version 1.1 software (Infostat Professional Group, Facultad de Ciencias Agrarias, Universidad Nacional de Córdoba, Argentina). The level of significance used was $P<0.05$.

\section{Results}

\subsection{Body Measurements}

L. limellum showed no differences in SVL, WE, or CF between environments (RF1 and RS1) $\left(\mathrm{F}_{\mathrm{SVL}}=2.0\right.$, $\left.P>0.05 ; \mathrm{F}_{\mathrm{WE}}=1.80 ; P>0.05 ; \mathrm{F}_{\mathrm{CF}}=2.44 ; P>0.05\right)$. $R$. bergi did not show differences in WE or $\mathrm{CF}\left(\mathrm{F}_{\mathrm{WE}}=\right.$ 3.91, $\left.\mathrm{P}>0.05 ; \mathrm{F}_{\mathrm{FC}}=1.09, \mathrm{P}>0.05\right)$ between environments; however, SVL was larger in individuals from the rice field than in those from the reference site $\left(\mathrm{F}_{\mathrm{SVL}}=\right.$ 4.46, $P<0.05$, Tukey post-test $P<0.05$ ) (Table 1$)$.

\subsection{Gonadal Morphology}

Testicular volume did not show significant differences between sites either in L. limellum $\left(\mathrm{F}_{\mathrm{TV}}=0.05, P>0.05\right)$ or in $R$. bergi $\left(\mathrm{F}_{\mathrm{TV}}=2.09, P>0.05\right)$ (Table 1).

The male reproductive system of both anurans species consisted of testes located in the anterior portion of the kidneys and covered by a tunica albuginea (Fig. 2). They were ovoid and were associated with fat bodies
(Fig. 2). The BO was located in the anterior pole of the testes in R. bergi (Fig. 2e).

In $L$. limellum, a great variation in testicular pigmentation was observed in RF1 individuals (Fig. 2b-d, Fig. $3 b-d)$. Four different pigmentation categories were observed in males from this site (category 3 , with $n=2$; category 2, $n=3$; and categories 0 and 1, n=2) (Fig. 2bd). In males from RS1, two categories were recorded (category $2 n=6$, category $1 n=1$ ) as shown in Fig. 2a. Morphologically, the presence of asymmetrical testis size was mostly observed in L. limellum from RF1 (18.51\%) (Fig. 2b). On the other hand, in R. bergi, testes of irregular size (16.66\%, fig. $2 \mathrm{~g}$ ), BO with enlarged follicles $(8.33 \%)$, and bilobed BO (8.33\%, Fig. 2f) were remarkable also in RF2.

\subsection{Histology of Male Gonads}

The testes of L. limellum and $R$. bergi had seminiferous tubules that contained numerous cysts with the germ cell line (Sg, ISc, IISc, Sp, Sz, and FSz) (Fig. 3 and Fig. 5).

\subsubsection{Lysapsus limellum}

The histological section of testes revealed connective tissue containing collagen fibers (slightly blue in GT stained cuts) and melanin among the seminiferous tubules (Fig. 3a). The mean number of cysts with spermatogenic cells at the early stages was significantly different between sites $(\mathrm{KW}=11.32, P<0.05)$, being higher in testes of individuals from the rice field than in those from the reference site (Fig. 4a, Table 1). The mean number of cysts with cells in late stages did not show significant differences between sites (Fig. 4a, Table 1). The proportion of seminiferous tubules with each score of $\mathrm{FSz}$ is summarized in Fig. 4c. L. limellum had a higher proportion of score zero tubules (without FSz) and a smaller proportion of score 3 tubules (with abundant FZs) in rice field than in reference site $\left({ }^{2}=P<0.05\right)$.

\subsubsection{Rhinella bergi}

The histological configuration of testes was similar to that described for L. limellum. The seminiferous tubules were well defined, although, unlike in this species, pigment cells were absent. The germ cell cysts were visible, and the Sertoli cell was observed in some cases (Fig. 5a, b). The mean number of cysts with spermatogenic cells in the early stages was significantly different 
Table 1 Biomarkers measured in Lysapsus limellum and Rhinella bergi from rice fields (RF 1 and RF 2) and reference sites (RS 1 and RS 2) in Santa Fe and Chaco provinces, respectively. References: Snout-vent length (SVL), animal body condition factor (CF), testicular volume (TV), cysts with spermatogenic cells in early stages (CES) and with spermatogenic cells in late stages (CLS), melanomacrophages (MMs), sinusoid enlargement (SE), dilation of blood vessels (DBV), hepatocyte vacuolization (HV), hypervascularization $(\mathrm{H})$

\begin{tabular}{|c|c|c|c|c|}
\hline \multirow[t]{2}{*}{ Biomarkers } & \multicolumn{2}{|c|}{ Lysapsus limellum } & \multicolumn{2}{|l|}{ Rhinella bergi } \\
\hline & RF 1 & RS 1 & RF 2 & RS 2 \\
\hline \multicolumn{5}{|c|}{ Morphological measurements } \\
\hline SVL (mm) & $16.81 \pm 1.81$ & $16.84 \pm 2.15$ & $36.5 \pm 3.62$ & $33.03 \pm 5.0$ \\
\hline Weight (g) & $0.60 \pm 0.10$ & $0.65 \pm 0.12$ & $3.78 \pm 0.95$ & $2.95 \pm 1.26$ \\
\hline $\mathrm{CF}$ & $0.005 \pm 0.001$ & $0.006 \pm 0.003$ & $0.14 \pm 0.15$ & $0.10 \pm 0.09$ \\
\hline $\operatorname{TV}\left(\mathrm{cm}^{3}\right)$ & $0.93 \pm 0.77$ & $0.80 \pm 0.44$ & $4.91 \pm 3.28$ & $1.44 \pm 0.83$ \\
\hline \multicolumn{5}{|c|}{ Testicular histological analyses } \\
\hline Number of CES & $16.61 \pm 8.10$ & $12.21 \pm 6.59$ & $6.23 \pm 2.44$ & $4.65 \pm 2.07$ \\
\hline Number of CLS & $9.21 \pm 7.33$ & $9.51 \pm 5.64$ & $10.95 \pm 7.10$ & $13.15 \pm 7.85$ \\
\hline \multicolumn{5}{|l|}{ Liver histological analysis } \\
\hline Histological alterations & SE, DBV & & $\mathrm{HV}, \mathrm{SE}, \mathrm{H}, \mathrm{DBV}$ & \\
\hline MM number & $43.33 \pm 19.69$ & $42.19 \pm 17.63$ & $20.19 \pm 7.0$ & $17.08 \pm 6.63$ \\
\hline
\end{tabular}

*Numbers in bold indicate significant differences $(P<0.05)$
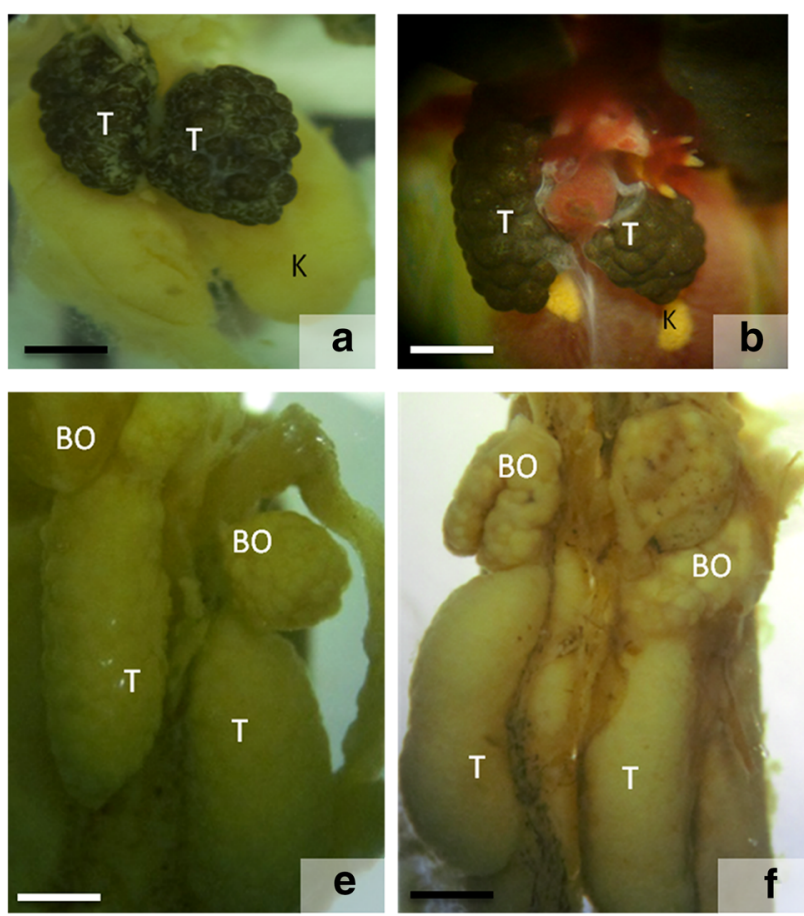

Fig. 2 Urogenital system morphology of Lysapsus limellum (a-d) and Rhinella bergi (e-g) observed under a stereoscopic magnifying glass. Individual from RS1 (a); individual from RF1 with irregular testis size and a massive amount of pigment cells (b), with absence of pigment cells (c) and a large amount of pigment
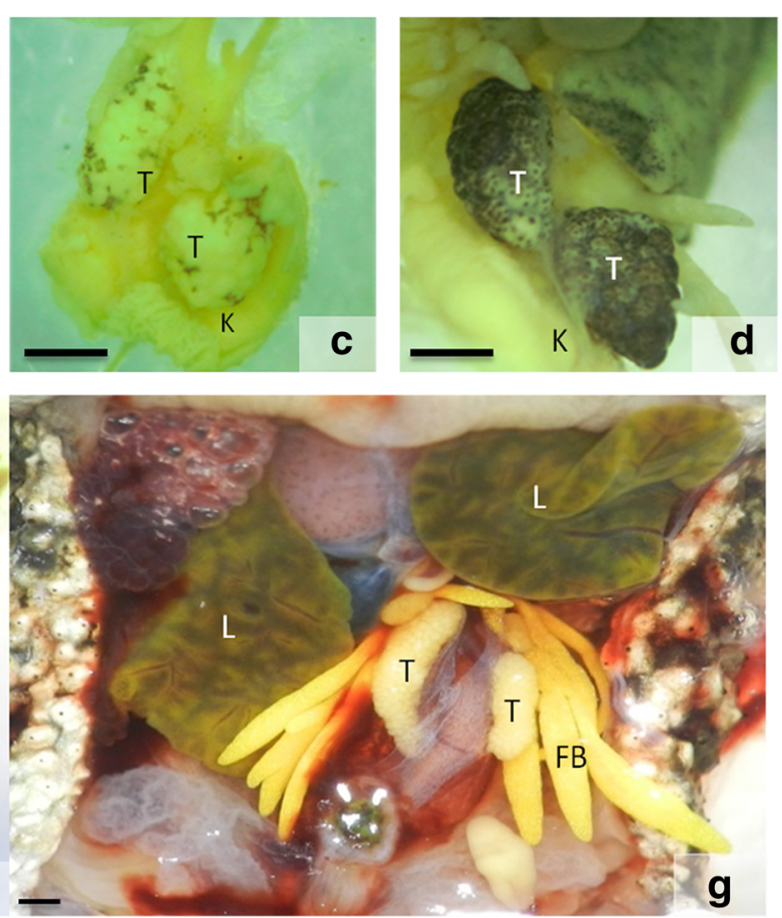

cells (d); individual from RS2 (e); individuals from RF2 with bilobed BO (f) and with irregular testis size (g). References: testis (T), kidney (K), fat body (FB), liver (L), Bidder organ (BO), scale bar: $1 \mathrm{~mm}$ 

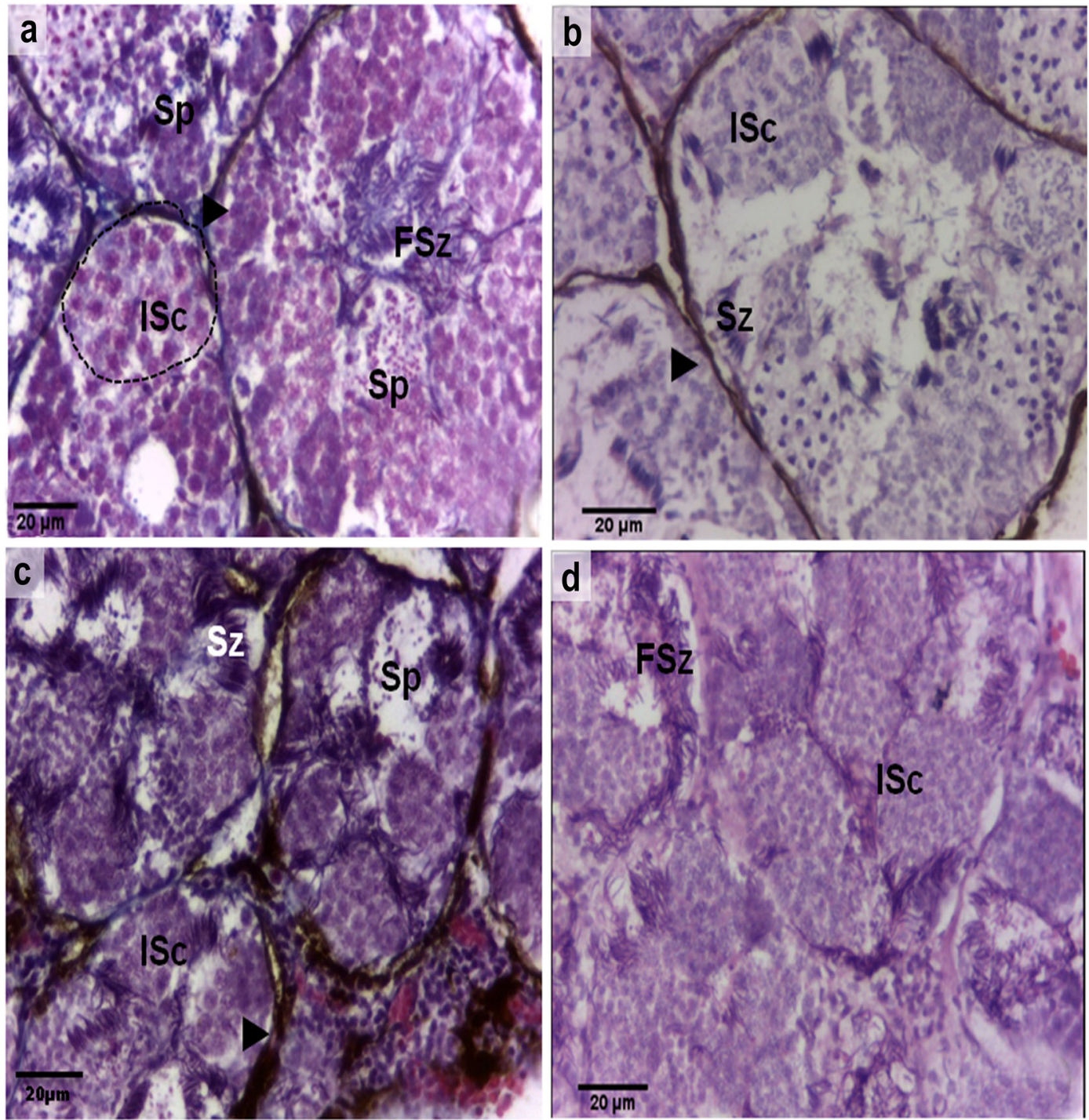

Fig. 3 Histological sections of Lysapsus limellum testes $(\times 40)$. Testis of an individual from RS1 showing the seminiferous tubules and ISc cyst (black cut line) (a); testis of an individual from RF1 with few germ cell cysts and pigmented testes (category 3) (b),

between sites $(\mathrm{KW}=11.04, P<0.05)$, being higher in testes of individuals from the rice field than in those from the reference site (Fig. 4c, Table 1). The mean number of cysts with cells in late stages did not show significant differences between sites (Fig. 4c, Table 1). The proportion of seminiferous tubules with each FSz score is summarized in Fig. 4d. The proportion of tubules with $\mathrm{FSz}$ scores 0 and 2 was significantly different between sites $\left({ }^{2}=P<0.05\right.$; Fig. $\left.4 \mathrm{~d}\right)$. with pigmentation category 2 (c) and pigmentation category 0 (d). References: spermatids (Sp), primary spermatocyte (ISc), free spermatozoa (FSz), spermatozoa (Sz), melanocytes (arrow head)

Histologically, BO consisted of two well-defined regions, cortex, and a medullary region (Fig. $5 \mathrm{c}$ ). In the cortex, Bidderian oocytes in previtellogenic stages, consisting of oocytes surrounded by follicular cells, were identified. In the medullary region, blood vessels and connective tissue with presence of fiber cells were observed (Fig. 5c). Vacuoles in BO $(33.33 \%$, atretic follicles in $\mathrm{BO}(66.66 \%)$ and pigmentary cells in the medullary region of $\mathrm{BO}(16.66 \%)$ were observed in $R$. bergi 

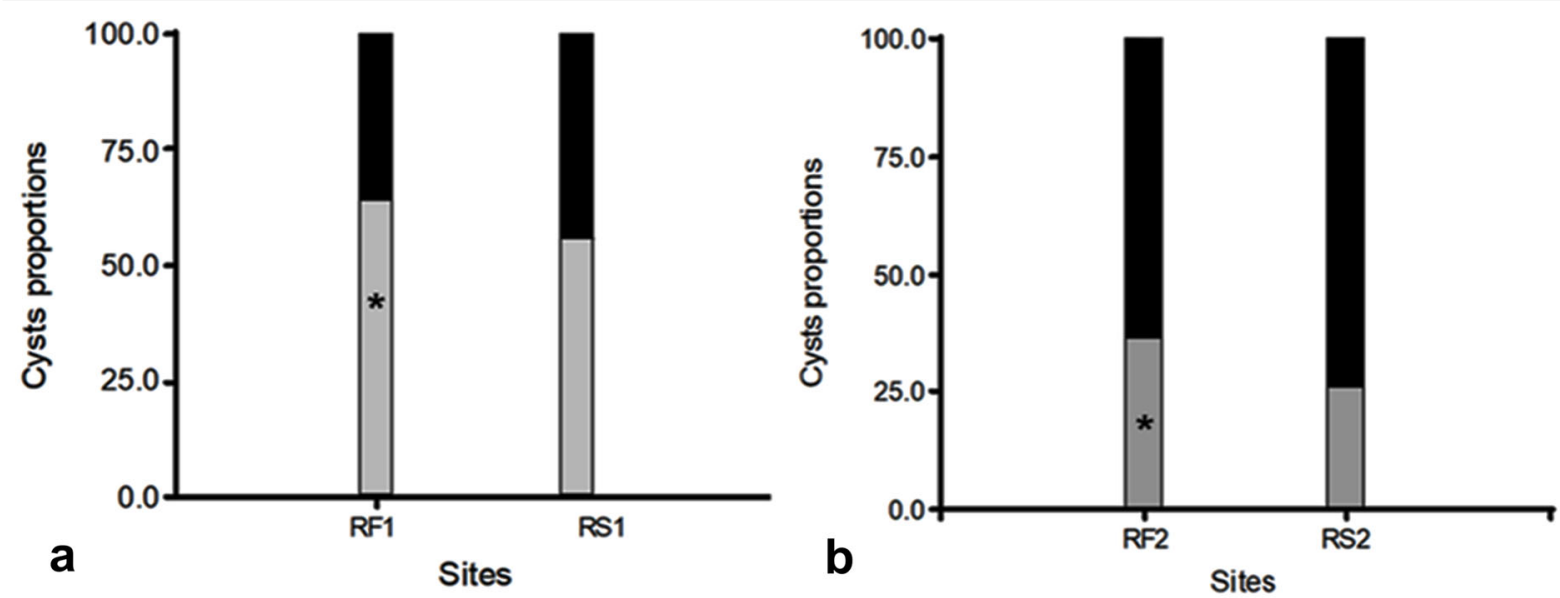

Cysts with early spermatogenic cells
Cysts with late spermatogenic cells

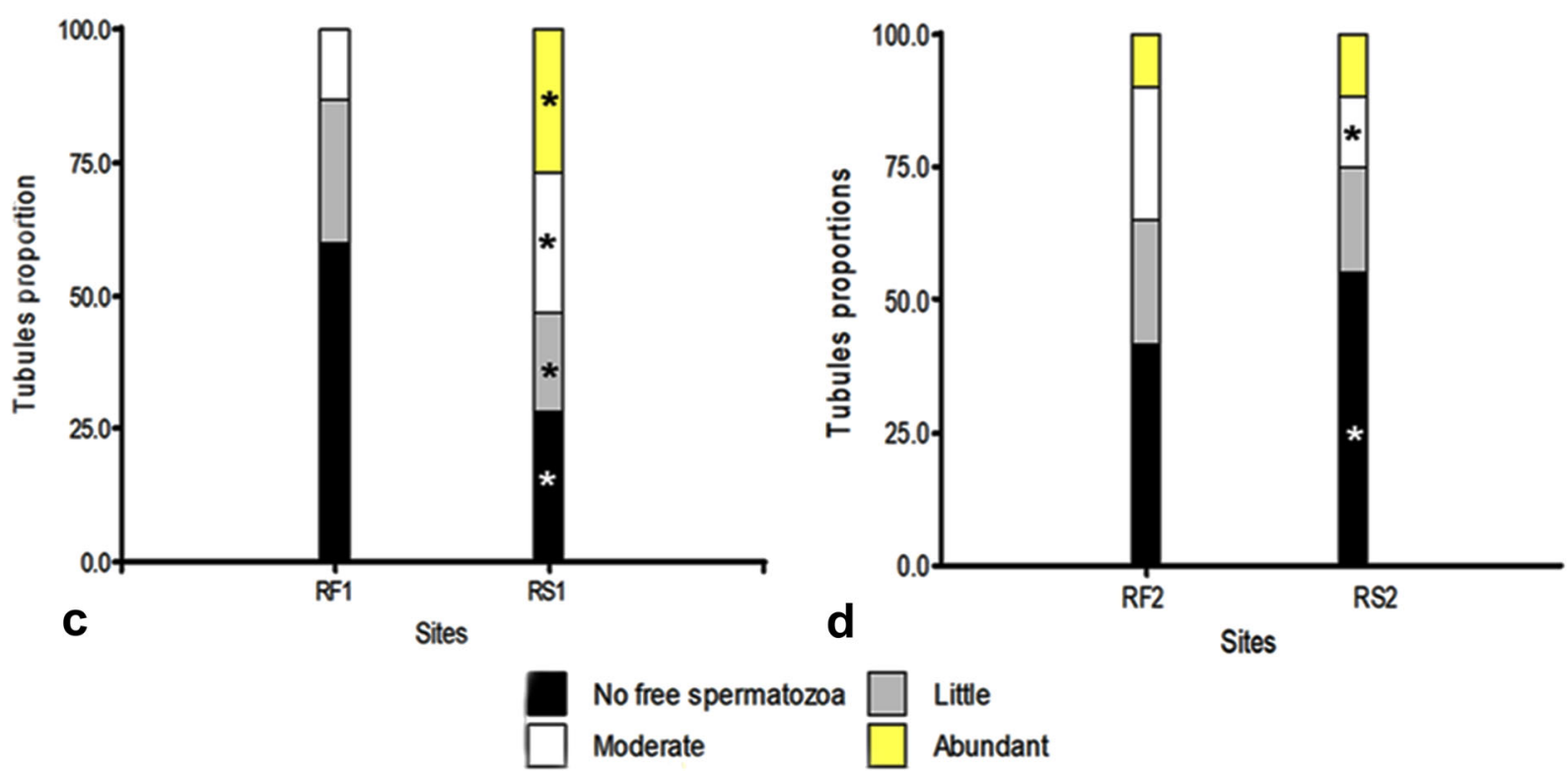

Fig. 4 Proportion of cell spermatogenic types in Lysapsus limellum and Rhinella bergi between sites. Mean number of cysts with early (Sg, ISc, and IISc) and late (Sp, Sz) spermatogenic

from the rice field (Fig. 5f, i). Three individuals with testicular oocytes were recorded from the reference site (Fig. 5e). Testicular tissue and BO connections in certain histological sections were also distinguished (Figs. $5 \mathrm{f}-\mathrm{h}$ ).

\subsection{Liver Histology}

In L. limellum and $R$. bergi from RS, the liver tissue presented hepatocytes in cordons surrounded by sinusoid stages in L. limellum (a) and R. bergi (b); number (scores) of free spermatozoa (FSz) in L. limellum (c) and Rhinella bergi (d). The asterisk $(*)$ indicates a significant difference

capillaries, veins, and MMs dispersed throughout the parenchyma were also identified (Fig. 6). Sinusoid enlargement $(37.71 \%)$ and dilated blood vessels $(5.55 \%)$ were observed (Fig. 6b, c), in the liver tissue of L. limellum from RF1 (Table 1). On the other hand, hepatocyte vacuolization (41.66\%, Fig. 6e), sinusoid enlargement (33.33\%, Fig. 6f), hypervascularization $(11.11 \%$, Fig. $6 \mathrm{e})$, and enlarged blood vessels $(5.55 \%)$ were recorded in $R$. bergi from RF 2 (Table 1). The number of MMs 

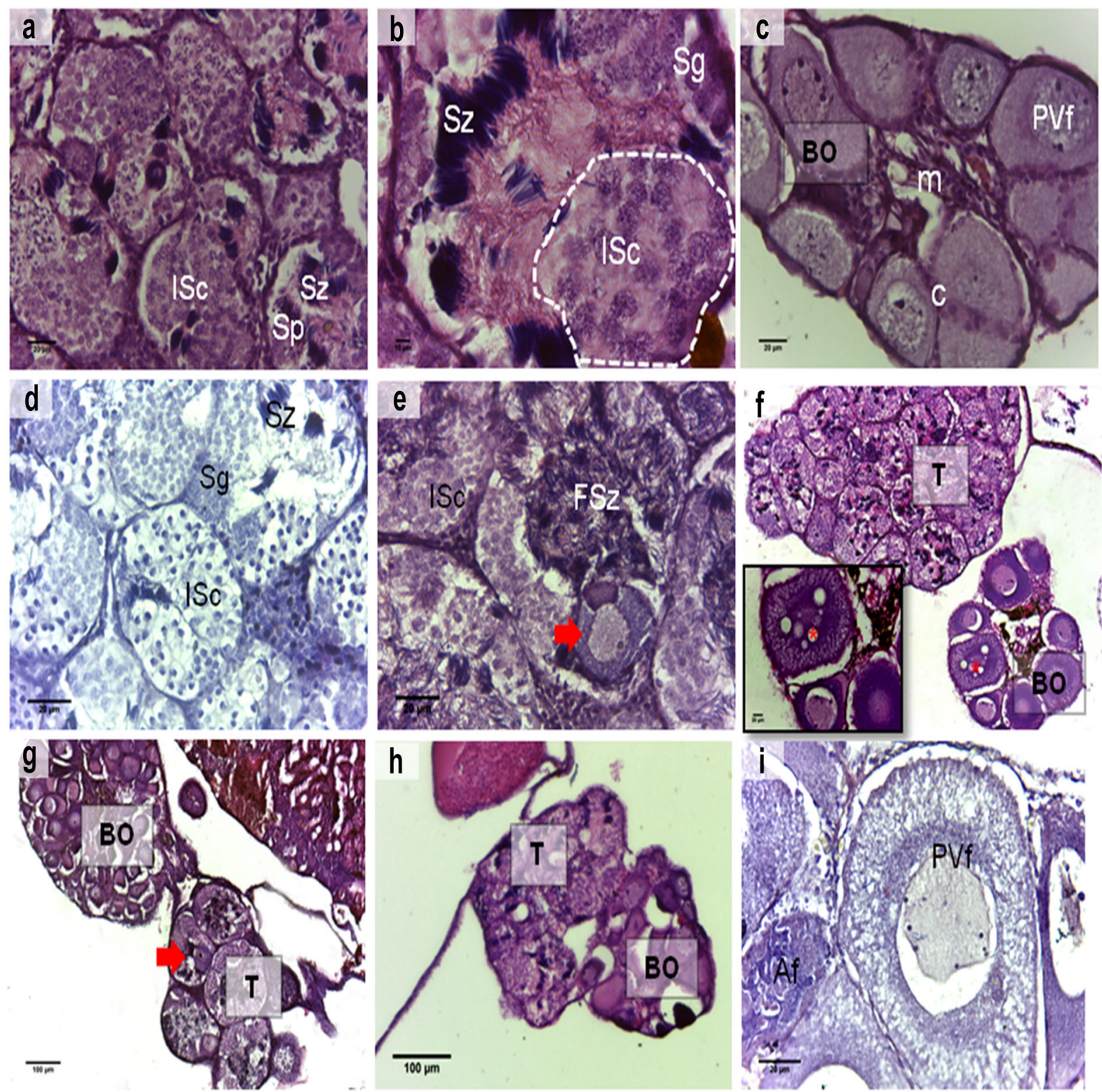

Fig. 5 Histological sections of testes and BO in Rhinella bergi. Testis section (a), detail of seminiferous tubules and ISc cyst (b), and BO structure in an individual from RS2 (c); testis with predominance of spermatogenic cell in early stages in an individual from RF2 (d); testicular oocytes in the testis of an individual from RS2 (e), testis and BO containing vacuoles in the Bidderian follicle and pigment cells in medullary region in an individual from RF 2 (f), presence of testicular oocytes in the testis near BO (g); details of testis and $\mathrm{BO}$ connections (h) and atretic follicles of BO in an individual from RF2 (i). References: testis (T), Bidder organ (BO), cortex (c), medullary region of BO (m), ISc (primary spermatocyte), Sg (spermatogonia), Sp (spermatid), Sz (spermatozoa), FSz (free spermatozoa), atretic follicle (Af), previtellogenic follicle (PVf), testicular oocyte (red arrow), vacuoles (asterisk), cyst of ISc (white cut line). a, c, d, e, i $(\times 40) ; \mathbf{b}(\times 100) ; \mathbf{g}, \mathbf{h}(\times 10)$ recorded in the liver tissue of L. limellum was similar between sites, but it was significantly higher $(\mathrm{KW}=4.13$, $P<0.05)$ in $R$. bergi from the rice field than in those collected from the reference site (Table 1).

\section{Discussion}

Two anuran species common in the agroecosystems, L. limellum and R. bergi, presented morphological and 

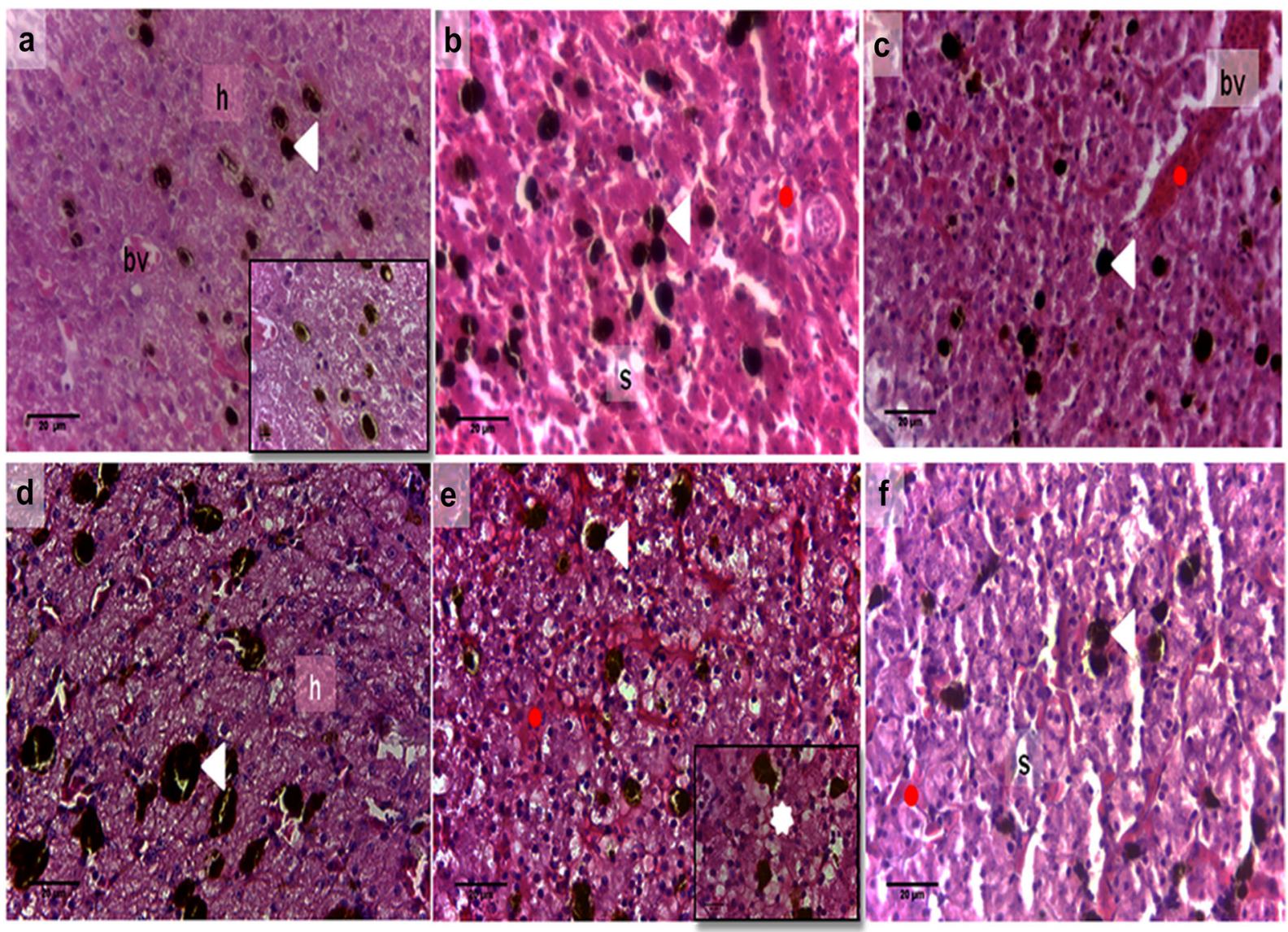

Fig. 6 Liver histological sections of L. limellum and R. bergi in $\times 40$. Liver section of $L$. limellum from RS1 (a); liver section with sinusoid enlargement (b) and dilated veins (c) in an individual from RF1; liver section of $R$. bergi from RS 2 (d); liver section with vacuolization of hepatocytes (e) and sinusoid enlargement (f) of an individual from RF2. References: hepatocytes (h), blood vessel (bv), sinusoid (s), melanomacrophages (white arrow), vacuolization (white asterisk), red blood cells (red circles) histological abnormalities in male gonads and liver tissue alterations of different intensity. These results highlight the importance of testing various anuran species under the same condition because species vary in sensitivity to agrochemicals within the community (Relyea \& Jones, 2009). A high number of pesticides is applied in Mideastern Argentina, the main rice production area (Attademo et al., 2015; Rossi et al., 2020), where $L$. limellum and $R$. bergi commonly occur (Vizgarra, 2018). Within this area, several studies demonstrated the presence of pesticide residues in dairy farm water (Demonte et al., 2018) and rainfall water samples (Alonso et al., 2018). Pesticide residues are frequently found to account for more than $80 \%$ of paddy rice monitored during the pre-harvest season (October and November 2018) where concentrations ranged between 11.6 and 43.6 times being higher than the maximum residues limits (see Medina et al., 2020). The presence of insecticides such as imidacloprid was detected in sediment samples from the RF1 (Attademo, Tamburi, et al., 2018b) as well as the presence of glyphosate, bifenthrin, azoxystrobin, and cyproconazole detected in water and sediment samples, bioaccumulating in fish species (Rossi et al., 2020).

The animal CF of L. limellum and $R$. bergi did not differ significantly between the rice fields and the reference sites. Similar results were found in $R$. fernandezae and Dendropsophus sanborni in three environments that differed in disturbance degrees (Sánchez, 2011). This result may be explained by the consumption of invertebrates with high nutrient value in agroecosystems (Bambaradeniya et al., 2004; Peltzer et al., 2010). In contrast, other studies recorded a lower CF in Pelophylax ridibundus occurring in contaminated areas 
(domestic wastewater and heavy metal contamination) compared to populations of uncontaminated areas (Zhelev et al., 2015, 2017). According to our results, only SVL differed in $R$. bergi, being higher in individuals from the rice field than in those from the reference site. However, this result may be attributed to the low number of males collected in the reference site from Chaco province.

The TV of L. limellum and $R$. bergi did not differ between environments. Martori et al. (2005) pointed out that the similarities in testicular volume of $R$. fernandezae from different environments may be due to the time of collection, which coincides with the species breeding season (spring-summer period). Conversely, Sánchez et al. (2014) found a decrease in testicular volume of $R$. fernandezae collected from environments with agricultural activities. Thus, external and internal causes (climatic conditions, intraspecific variations, reproductive stage, and age) may affect this parameter (Huang et al., 1997). In our study, it was not possible to relate agrochemicals to testicular volume. Difference in size between the right and left testes was also recorded in both species from rice fields, but the proportion was low. A similar result was recorded for R. fernandezae and D. sanborni in agricultural areas (Sánchez, 2011). Jooste et al. (2005) explained that the cause of these anomalies might be due to a delay in the testis maturation. Gonad abnormalities were few registered in our study. These controversial results are exposed by other authors who demonstrated that there were no significant effects on amphibian gonad morphology between agriculture and non-agriculture environments (Du Preez et al., 2005; Smith et al., 2005; Spolyarich et al., 2011).

Testicular pigmentation is part of an extracutaneous pigmentary system whose function is poorly understood (De Oliveira \& Zieri, 2005). In L. limellum, variation in pigmentation was much greater in individuals from the rice field than in those from the reference site. However, these variations cannot be linked with a specific cause of environmental contamination. Few studies investigated how environmental variables influence the coloration of testes (Franco-Belussi et al., 2017). In addition, intracellular transport and the aggregation of melanin were inhibited after Roundup formulation exposure in Xenopus laevis (Hedberg \& Wallin, 2010). The existence of an intraspecific variation between individuals may play a role in pigmentation expression, as noted for Dendropsophus and Scinax (Franco-Belussi et al.,
2017). Melanocytes present in gonads would be expected to protect the tissues from oxidative damage, toxic agents, DNA damage, or UV, similarly to extracutaneous pigment types (Franco-Belussi et al., 2016; Zieri et al., 2015). The testicular pigmentation pattern in gonads should be analyzed under different environmental conditions and also at different life stages (tadpoles, juveniles, adults) for to have a more comprehensive analysis of other factors that may influence.

Histological analysis of testes revealed that L. limellum and $R$. bergi have a similar structure and cellular composition to those of other anurans species (De Oliveira et al., 2003; De Souza Santos \& De Oliveira, 2008). Spermatogenic activity in L. limellum is classified as continuous in Pantanal (Mato Grosso do Sul, Brazil) by Ferreira et al. (2008); i.e., the testes contain cells in all stages of maturation in seminiferous tubules throughout the year. A higher proportion of cysts with cells in the early spermatogenesis stages were observed in L. limellum from the rice field than in those from the reference site. Moderate and abundant number of free spermatozoa in the lumen of tubules was observed in testes of frogs from the reference site. More studies are necessary to relate hormonal disruptions and alteration of the spermatogenic process in amphibians from agroecosystems. Plasma testosterone concentration in males from agricultural areas was also recorded in $B$. marinus, a species that is frequent in agricultural areas (McCoy et al., 2008); it has been recently hypothesized that the reduction in the spermatogenic cell number is due to some alterations in the functioning of the hypothalamus or pituitary gland in these species (McCoy et al., 2017). Similarly, the number of spermatogonial cell nests decreased in atrazine-exposed tadpoles compared to control; it represented a 70\% reduction in spermatogonial nests (Tavera-Mendoza et al., 2002). The proportion of cysts with cells in the early spermatogenesis stage was higher in $R$. bergi from the rice field than in those from the reference site. In contrast, the number of free spermatozoa was similar in both sites. This toad has an explosive reproduction that occurs in a few days (Cei, 1980), which may explain the scarce number of free spermatozoa in the collection days. Since L. limellum is an extremely aquatic frog, it is expected that this species would be more exposed to agrochemicals due to high transdermal exposure during metamorphosis in water altering as consequence the spermetagenic processes. Attademo et al. (2015) documented approximately 3-4 L. limellum dead frogs per 
$\mathrm{m}^{2}$ after aircraft chlorpyrifos application in the same rice field.

On the other hand, the histological analysis revealed the presence of testicular oocytes embedded in the testicular tissue in three $R$. bergi individuals from the reference site. The cause of the presence of testicular oocytes in anurans has not been completely elucidated (Lent et al., 2019; Orton \& Tyler, 2014). Sánchez (2011) also observed this structure in $R$. fernandezae and $D$. sanborni and found that it was not exclusive of contaminated sites. Skelly et al. (2010) reported a high frequency of testicular oocytes in Lithobates clamitans from the suburban environment $(21 \%)$ and $6 \%$ in the agricultural environment. Therefore, they did not mention an association between this structure and agricultural cover. However, McCoy et al. (2008) found that the number and frequency of gonadal abnormalities, such as intersex individuals (gonads containing ovarian and testicular tissue) of Rhinella marina increased along a gradient of increasing agricultural activity. The presence of testicular oocytes found in $R$. bergi testes cannot be considered a histological alteration. The oocytes observed inside the testicular tissues probably correspond to an adjacent Bidder organ follicle due to the nearest between these organs and the fact that transverse cuts were made.

The BO structure is similar to that described for the species, such as Rhinella dypticha (Freitas et al., 2015), Bufo bufo (Falconi et al., 2007), and Rhinella icterica (Farias et al., 2002). Pigmentary cells were observed in $R$. bergi from the rice field. As suggested by Freitas (2013), these cells may have phagocytic activity and be an adaptive characteristic of $R$. dyptica to the environment (Freitas et al., 2015). Furthermore, toads from RF presented atretic follicles and cortical vacuoles. The cortical vacuoles have been also reported in R. schneideri males exposed to $17 \beta$ estradiol for 3 to 7 days (Freitas, 2013).

No significant differences were found in the number of MMs in L. limellum frogs between sites. Nevertheless, in R. bergi, a higher number of MMs was recorded in the rice field than in reference site. In this sense, the use of MMs is a useful histological biomarker of oxidative stress in some anuran tadpoles (Bach et al., 2018; Curi et al., 2019; Pérez Iglesias et al., 2019) and adult anurans exposed to different agrochemicals under laboratory conditions (Cakici, 2015; De Gregorio et al., 2016; Paunescu et al., 2010; Pérez Iglesias et al., 2016). Nevertheless, studies about individuals collected from natural environments are scarce. Huespe et al. (2017) found a greater number of MMs, which were occupying a larger area in livers of Leptodactylus macrosternum adults from a rice crop collected seven days after chlorpyrifos application compared to a reference site. The presence of different compounds like contaminants of emerging concern in aquatic environments where anurans develop could be another possible explanation of the MMs presence in anurans from the forest environment. Additionally, toads from rice fields presented other histological alterations (sinusoid enlargement, dilated blood vessels, hepatocyte vacuolization). These alterations were also observed in livers of Physalaemus albonotatus and Leptodactylus luctatur tadpoles exposed to 2,4-D Amina Zamba® and Roundup Ultramax and glyphosate, respectively (Bach et al., 2018; Curi et al., 2019). Recently, Pérez Iglesias et al. (2019) found an increase in vascularization and enlargement of hepatic sinusoids in $R$. schneideri tadpoles after exposure to atrazine (SIPTRAN 500SC $($ ) for 48 and $96 \mathrm{~h}$ and concluded that this herbicide has hepatotoxic capacity.

\section{Conclusions}

The assessment of chronic agrochemical exposure in amphibians occurring in rice fields should include morphological parameters and histological analysis of target organs (gonad and liver) to characterize the risk at different biological levels. The result of the histological analysis of testes varied between anuran species. An altered spermatogenic pattern was observed only in L. limellum males from the rice field. Further analysis is needed to determine if amphibian species are suffering reduced fertility or other reproductive health disorders at population level (McCoy et al., 2017). Furthermore, the Bidder organ is a useful target organ to be used in the evaluation of pesticide effects on Bufonids. Histopathological liver lesions in anurans may be the result of long-term exposure to agrochemicals in rice fields. The increase in MMs indicates high oxidative stress in $R$. bergi from the rice field in contrast to the reference site. We also confirmed the use of liver MMs as a biomarker of agrochemical exposure on some adult anurans.

The sublethal effects analyzed in natural populations of $L$. limellum and $R$. bergi at the histological level give a relevant and realistic scenario and highlight the 
dissimilarities in species sensitivity and responses. The rice fields environments imply a high risk in these to anuran species, which frequently occur in those environments. Moreover, these two species are useful as bioindicator species of pesticide contamination and disruption of reproduction. Further, a battery of biomarkers at different levels (morphological, histological, but also physiological, biochemical, molecular, etc.) is needed to understand the pathways evolved in reproductive abnormalities (Abdel-moneim et al., 2015).

Acknowledgements We are grateful to J. A. Ruiz García, S. Seib, A. Bassó, and J. Céspedez for their help with field sampling and to T. Sandoval for assistance in laboratory procedures. We also thank Wildlife and Natural Areas department of Chaco Provinces and Environment Ministry of Santa Fe province for providing the collection authorizations and to CONICET (Consejo Nacional de Investigaciones Científicas y Técnicas) for providing financial support as fellowships during the first author's Doctoral thesis. We are also grateful to Jorgelina Brasca for English editing and comments. This work was supported by Curso de Acción para la Investigación y Desarrollo (Programa de I+D Orientado a Problemas Sociales y Productivos, Uiversidad Nacional del Litoral-UNL).

\section{Availability of Data and Material Not applicable}

\section{Code Availability Not applicable}

Author Contribution All authors contributed to the study conception and design. Field work, laboratory activities, and analysis were performed by Curi, L.M. The first draft of the manuscript was written by Curi, L.M. The field work and the commented on the previous version of manuscript were performed by Peltzer, P.M., Attademo, M..A., and Lajmanovich R.C. All authors read and approved the final manuscript.

\section{Declarations}

Ethics Approval Animal used in this research was treated following the American Society of Ichthyologists and Herpetologists (2004) guidelines and with the approval of the Committee of Bioethics of the Facultad de Bioquímica y Ciencias Biológicas of the Universidad Nacional del Litoral, Santa Fe, Argentina (Res. CD. N³88/06), http://www. fbcb.unl.edu.ar/pages/investigacion/ comite-de-etica.php.

Consent to Participate All authors are consent to participate.

Consent for Publication All authors are consent for publication.

Conflict of Interest The authors declare no competing interests.

\section{References}

Abdel-moneim, A., Coulter, D. P., Mahapatra, C. T., \& Sepúlveda, M. S. (2015). Intersex in fishes and amphibians: Population implications, prevalence, mechanisms and molecular biomarkers. Applied Toxicology, 35, 1228-1240.

Alonso, L. L., Demetrio, P. M., Etchegoyen, M. A., \& Marino, D. J. (2018). Glyphosate and atrazine in rainfall and soils in agroproductive areas of the pampas region in Argentina. Science of the Total Environment, 645, 89-96.

Apodaca, M. J., Crisci, J. V., \& Katinas, L. (2015). Las provincias fitogeográficas de la Republica Argentina: definición y sus principales áreas protegidas. In R. R. Casas \& G. F. Albarracin (Eds.), El deterioro del suelo y del ambiente en la Argentina (pp. 79-101). Fundación Ciencia Educación y Cultura.

Asih, HL, SSAR. (2004). American Society of Ichthyologists and Herpetologists. Guidelines for Use of Live Amphibians and Reptiles in Field and laboratory Research. http://asih. org/sites/default/files/documents/resources/guidelines herpsresearch2004.pdf/. Accesed 10 August 2018.

Attademo, M. A., Peltzer, P. M., \& Lajmanovich, R. C. (2005). Amphibians occurring in soybean and implications for biological control in Argentina. Agriculture, Ecosystems and Environment, 106(4), 389-394.

Attademo, M. A., Cabagna-Zenklusen, M., Lajmanovich, R. C., Peltzer, P. M., Junges, C., \& Bassó, A. (2011). B-esterase activities and blood cell morphology in the frog Leptodactylus chaquensis (Amphibia: Leptodactylidae) on rice agroecosystems from Santa Fe Province (Argentina). Ecotoxicology, 20, 274-282.

Attademo, A. M., Peltzer, P. M., Lajmanovich, R. C., CabagnaZenklusen, M., Junges, C. M., Lorenzatti, E., et al. (2015). Biochemical changes in certain enzymes of Lysapsus llimellum (Anura: Hylidae) exposed to chlorpyrifos. Ecotoxicology and Environmental Safety, 113, 287-294.

Attademo, A. M., Lorenzón, R. E., Peltzer, P. M., \& Lajmanovich, R. C. (2018a). Diversity of anurans in rice fields under organic and conventional management in Santa Fe province, Argentina. Herpetological Review, 49(4), 632-635.

Attademo, M. A., Tamburi, N. E., Peltzer, P. M., Lajmanovich, R. C., \& Martinuzzi, C. (2018b). Metabolic stress and Shell thining in Pomacea canaliculata (Caenogastropoda, Ampullaridae) in rice agroecosystems of Argentina. Current Topics in Toxicology, 14, 53-65.

Bach, N. C., Marino, D. J. G., Natale, G. S., \& Somoza, G. M. (2018). Effects of glyphosate and its commercial formulation, Roundup ${ }^{\circledR}$ Ultramax, on liver histology of tadpoles of the Neotropical frog, Leptodactylus latrans (Amphibia: Anura). Chemosphere, 202, 289-297.

Bagenal, T. B., \& Tesch, F. W. (1978). Methods for assessment of fish production in freshwaters. In T. B. Bagenal (Ed.), Age and Growt (pp. 101-136). Blackwell Scientific Publications.

Bambaradeniya, C. N. B., Edirisinghe, J. P., De Silva, D. N., Guntilleke, C. V. S., Ranawana, K. B., \& Wijekoon, S. (2004). Biodiversity associated with an irrigated rice agroecosystem in Sri Lanka. Biodiversity and Conservation, 13(9), 1715-1753. 
Bernabó, I., Biasone, P., Macirella, R., Tripepi, S., \& Brunelli, E. (2014). Liver histology and ultrastructure of the Italian newt (Lissotriton italicus): Normal structure and modifications after acute exposure to nonylphenol ethoxylates. Experimental and Toxicologic Pathology, 66(9e10), $455 \mathrm{e} 468$

Burkart, R., Barbaro, N. O., Sánchez, R. O., \& Gómez, D. A. (1999). Eco-regiones de la Argentina. PRODIA.

Cakici, O. (2015). Histopathologic changes in liver and kidney tissues induced by carbaryl in Bufotestes variabilis (Anura: Bufonidae). Experimental and Toxicologic Pathology, 67, 237-343.

Cei, J. M. (1980). Amphibians of Argentina. Monitore Zoologico Italiano. Italian Journal of Zoology. Monograph, 2.

Cevasco, A., Urbatzka, R., Bottero, S., Massari, A., Pedemonte, F., Kloas, W., \& Mandich, A. (2008). Endocrine-disrupting chemicals (EDC) with (anti)estrogenic and (anti)androgenic modes of action affecting reproductive biology of Xenopus laevis: II. Effects on gonad histomorphology. Comparative Biochemistry and Physiology Part C, 147(2), 241-251.

Chai, L., Chen, A., Luo, P., Zhao, H., \& Wang, H. (2017). Histopathological changes and lipid metabolism in the liver of Bufo gargarizans tadpoles exposed to triclosan. Chemosphere, 182, 255-266.

Coady, K. K., Murphy, M. B., Villanueve, D. L., Hecker, M., Jones, P. D., Carr, J. A., et al. (2005). Effects of atrazine on metamorphosis, growth, laryngeal and gonadal development, aromatase activity, and sex steroid concentrations in Xenopus laevis. Ecotoxicology and Environmental Safety, 62(2), 16173.

Crump, M. L., \& Scott, N. J. (2001). Relevamiento por encuentros visuales. In W. R. Heyer, M. A. Donolly, R. W. McDiarmid, C. Hayek, \& M. S. Foster (Eds.), Medición y monitoreo de la diversidad biológica, Métodos estandarizados para anfibios (pp. 80-87). Editorial universitaria de la Patagonia.

Curi, L. M., Céspedez, J. A., \& Álvarez, B. B. (2014). Composición, distribución espacial y actividad de vocalización de un ensamble de anuros dentro de la región fitogeográfica del Chaco Oriental. Revista Mexicana de Biodiversidad, 85(4), 1197-1205.

Curi, L. M., Peltzer, P. M., Sandoval, M. T., \& Lajmanovich, R. C. (2019). Acute Toxicity and sublethal effects caused by a commercial herbicide formulated with $2,4 \mathrm{D}$ on Physalaemus albonotatus tadpoles. Water, Air, and Soil Pollution, 230, 22.

De Gregorio, L. S., Franco-Belussi, L., Gomes, F. R., \& De Oliveira, C. (2016). Flutamide effects on the morphology of reproductive organs and liver of Neotropical anura, Rhinella schneideri. Aquatic Toxicology, 176, 181-189.

De Oliveira, C., \& Zieri, R. (2005). Testicular pigmentación in Physalaemus nattereri (Steindachner) (Amphibia, Anura) with anatomical observations on the extracutaneous pigmentary system. Revista Brasilera de Zoología, 22(2), 454-460.

De Oliveira, C., Vicentini, C. A., Taboga, S. R., Oliveira, C., Vicentini, C. A., \& Taboga, S. R. (2003). Structural characterization of nuclear phenotypes during Scinax fuscovarius spermatogenesis (Anura Hylidae). Caryologia, 56(1), 75-83.

De Oliveira, C. R., Fraceto, L. F., Rizzi, G. M., Salla, R. F., Abdalla, F. C., Costa, M. J., \& Silva-Zacarin, E. C. M.
(2016). Hepatic effects of the clomazone herbicide in both its free form and associated with chitosan-alginate nanoparticles in bullfrog tadpoles. Chemosphere, 149, 304-313.

De Souza Santos, L. R., \& De Oliveira, C. (2008). Histological aspects and structural characteristics of the testes of Dendropsophus minutus (Anura: Hylidae). Micron, 39(8), 1266-1270.

Demonte, L. D., Michlig, N., Gaggiotti, M., Adam, C. G., Beldoménico, H. R., \& Repetti, M. R. (2018). Determination of glyphosate, AMPA, and glufosinate in dairy farm water from Argentina using a simplified UHPLC-MS/MS method. Science of the Total Environment, 645, 34-43.

Du Preez, L. H., Solomon, K. R., Carr, J. A., Giesy, J. P., Gross, T. S., Kendall, R. J., et al. (2005). Population structure of the African clawed frog (Xenopus laevis) in maize-growing areas with atrazine application versus non-maize growing areas in South Africa. African Journal of Herpetology, 54(1), 61-68.

Dunham, A. E. (1981). Populations in a fluctuating environment: The comparative population ecology of the iguanid lizards Sceloporus merriami and Urosauru ornatus. Miscellaneous Publications of the Museum of Zoology, University of Michigan, 158, 1-62.

Duré, M. I., \& Kehr, A. I. (2001). Differential explotation of trophic resources by two pseudid Frogs from Corrientes, Argentina. Journal of Herpetology, 3(2), 340-343.

Duré, M. I., Kehr, A. I., Schaefer, E. F., \& Marangoni, F. (2008). Diversity of amphibians in rice fields from northeastern Argentina. Interciencia, 33(7), 523-527.

Egea-Serrano, A., Relyea, R. A., Tejedo, M., \& Torralva, M. (2012). Understanding of the impact of chemicals on amphibians: A meta-analytic review. Ecology and Evolution, 2(7), 1382-1397.

Falconi, R., Dalpiaz, D., \& Zaccanti, F. (2007). Morphological aspects of gonadal morphogenesis in Bufo bufo (Amphibia, Anura): Bidder's organ differentiation. The Anatomical Records, 290, 801-813.

Farias, C. F., Carvalho, E., Silva, S. P., \& Brito-Gitirana, L. (2002). Bidder's organ of Bufo ictericus: a light and electron microscopy analysis. Micron, 33(7-8), 673-679.

Fenoglio, C., Boncompagni, E., Fasola, M., Gandini, C., Comizzoli, S., Milanesi, G., \& Barni, S. (2005). Effects of environmental pollution on the liver parenchymal cells and Kupffer-melanomacrophagic cells of the frog Rana esculenta. Ecotoxicology and Environmental Safety, 60(3), 259-268.

Ferreira, A., Mehanna, M., \& Prado, C. P. A. (2008). Morphologic and morphometric analysis of testis of Pseudis limellum (Cope, 1862) (Anura, Hylidae) during the reproductive cycle in the Pantanal, Brazil. Biocell, 3(2), 185-194.

Franco-Belussi, L., Skold, H. N., \& De Oliveira, C. (2016). Internal pigment cells respond to external UV radiation in frogs. Journal of Experimental Biology, 219, 1378-1383.

Franco-Belussi, L., Provete, D. B., \& De Oliveira, C. (2017). Environmental correlates of internal coloration in frogs vary throught space and lineages. Ecology and Evolution, 7(22), 9222-9233.

Freitas, S. J. (2013). Efeito do hormônio $17 \beta$-estradiol na gametogênese dos órgãos de Bidder e testículos e no tecido 
hepático em machos de Rhinella schneideri (Anura: Bufonidae). Disertacion de Maestria en Biologia Animal. Universidad Estadual Paulista "Julio de Mesquita Filho". Sao Jose de Rio Preto

Freitas, S. J., Franco-Belussi, L. F., \& De Oliviera, C. (2015). Morphological and histochemical studies of Bidder's organ in Rhinella schneideri (Amphibia: Anura) males. The Italian Journal of Zoology, 82, 479-488.

Gyllenhammar, I., Holm, L., Eklund, R., \& Berg, C. (2009). Reproductive toxicity in Xenopus tropicalis after developmental exposure to environmental concentrations of ethynylestradiol. Aquatic Toxicology, 91(2), 171-178.

Hayes, T. B., Stuart, A. A., Mendoza, M., Collins, A., Noriega, N., Vonk, A., Johnston, G., Liu, R., \& Kpodzo, D. (2006a). Characterization of atrazine-induced gonadal malformations in African clawed frogs (Xenopus laevis) and comparisons with effects of an androgen antagonist (cyproterone acetate) and exogenous estrogen (17 b-estradiol): Support for the demasculinization/feminization hypothesis. Environmental Health Perspectives, 114(1), 134-141.

Hayes, T. B., Case, P., Chui, S., Chung, D., Haeffele, C., Haston, K., Lee, M., Phoung Mai, V., Marjuoa, Y., Parker, J., \& Tsui, M. (2006b). Pesticide mixtures, endocrine disruption, and amphibian declines: Are we underestimating the impact? Environmental Health Perspectives, 114(1), 40-50.

Hayes, T. B., Khoury, V., Narayan, A., Nazir, M., Park, A., Brown, T., Adame, L., Chan, E., Buchholz, D., Stueve, T., \& Gallipeau, S. (2010). Atrazine induces complete feminization and chemical castration in male African clawed frogs (Xenopus laevis). Proceedings of the National Academy of Sciences of the United States of America, 107(10), 46124617.

Hecker, M., Murphy, M. B., Coady, K. K., Villenueve, D. L., Jones, P. D., Carr, J. A., et al. (2006). Terminology of gonadal anomalies in fish and amphibians resulting from chemical exposures. Reviews of Environmental Contamination and Toxicology, 187, 103-131.

Hedberg, D., \& Wallin, M. (2010). Effects of Roundup and glyphosate formulations on intracellular transport, microtubules and actin filaments in Xenopus laevis melanophores. Toxicology In Vitro, 24, 795-802.

Howe, C. M., Berrill, M., Pauli, B. D., Helbing, C. C., Werry, K., \& Veldhoen, N. (2004). Toxicity of glyphosate-based pesticides to four North American frog species. Environmental Toxicology and Chemistry, 23(8), 1928-1938.

Huang, W. S., Lin, J. Y., \& Yu, J. Y. L. (1997). Male reproductive cycle of the toad Bufo melanosticus in Taiwan. Zoological Science, 14(3), 497-503.

Huespe, I., Cabagna-Zenklusen, M., Curi, L. M., Attademo, M. A., Villafañe, N., \& Lajmanovich, R. (2017). Melanomacrofagos hepáticos y actividad de la enzima Glutation S-Transferasa en Leptodactylus chaquensis (Leptodactylidae) como biomarcadores de estrés oxidativo por la exposición a Clorpirifos. Acta Biológica Colombiana, 22(2), 234-237.

Jantawongsri, K., Thammachoti, P., Kitana, J., Khonsue, W., Vatanusupakul, P., \& Kitana, N. (2015). Altered inmune response of the rice frog Fejervarya limnocharis living in agricultural area with intensive herbicide utilization at Nan province, Thailand. EnvironmentAsia, 8(1), 68-74.
Jooste, A. M., Du Preez, L. H., Carr, J. A., Giesy, J. P., Gross, T. S., Kendall, R. J., et al. (2005). Gonadal development of larval male Xenopus laevis exposed to atrazine in outdoor microcosms. Environmental Science and Technology, 39(14), 5255-5261.

Khatiwada, J. R., Ghimire, S., Paudel, S. P., Bischof, B., Jiang, R., \& Haugaasen, T. (2016). Frogs as potential biological control agents in the rice fields of Chitwan, Nepal. Agriculture, Ecosystems and Environment, 230, 307-314.

Kloas, W., Lutz, I., Springer, T., Krueger, H., Wolf, J., Holden, L., et al. (2009). Does atrazine influence larval development and sexual differentiation in Xenopus laevis? Toxicological Sciences, 107(2), 376-384.

Kole, P. C., Chakraborty, N. R., \& Bhat, J. S. (2010). Analysis of variability, correlation and path coefficients in induced mutants of aromatic non-basmati rice. Tropical Agriculture Research and Extension, 11, 60-64.

Lajmanovich, R. C., Sánchez-Hernández, J. C., Stringhini, G., \& Peltzer, P. M. (2004). Levels of Serum Cholinesterase Activity in the Rococo Toad (Bufo paracnemis) in Agrosystems of Argentina. Bulletin of Environmetal Contamination and Toxicology, 72(3), 586-591.

Lajmanovich, R. C., Peltzer, P. M., Attademo, M. A., Martinuzzi, C. S., Simoniello, M. F., Colussi, C. L., Cuzziol Boccioni, A. P., \& Sigrist, M. (2019). Fisrts evaluation of novel potential synergistic effectos of glyphosate and arsenic mixture on Rhinella arenarum (Anura: Bufonidae) tadpoles. Heliyon, 5, e02601.

Lent, E. M., Babbit, K. J., \& Sower, S. A. (2019). Gonadal histology and reproductive steroidogenesis in Lithobates pipiens exposed to atrazine. Toxicological and Environmental Chemistry, 100(5-7), 583-600.

Lorenzón, R. E., León, E. J., Juani, M., Beltzer, A. H., Peltzer, P. M., Lajmanovich, R. C., \& Attademo, M. A. (2020). Can agroecological management increase functional diversity of birds in rice fields? Revista de Biología Tropical, 68(3), 873883.

Loumbourdis, N. S. (2007). Liver histopathologic alterations in the anuran Rana ridibunda from a small river of Northern Greece. Archives of Environmental Contamination and Toxicology, 53, 418-442.

Martori, M., Aún, L., Birri, A., Rozzi, G., \& C. (2005). Reproducción comparada de tres especies de anuros sintópicos de una localidad del sudeste de Córdoba. Cuadernos de Herpetología, 18, 43-59.

Matthiessen, P., Wheeler, J. R., \& Weltje, L. (2018). A review of the evidence for endocrine disrupting effects of current-use chemicals on wildlife populations. Critical Reviews in Toxicology, 48(3), 195-216.

McCoy, K. A., Bortnick, L. J., Campbell, C. M., Hamlin, H. J., Guillette, J. R., \& Mary, C. M. (2008). Agriculture alters gonadal form and function in the toad Bufo marinus. Environmental Heatlh Perspectives, 116(11), 1526-1532.

McCoy, K. A., Amato, C. M., Guillete Jr., L. J., \& Mary, C. M. (2017). Giant toads (Rhinella marina) living in agricultural areas have altered spermatogenesis. Science of the Total Environment, 609, 1230-1237.

Medina, M. B., Munitz, M. S., \& Resnik, S. L. (2020). Validation and expanded uncertainly determination of pesticides in water; and their survey on paddy rice irrigation water from 
Argentina. Journal of Environmental Science and Health, Part B, 55(11), 983-989.

Mnif, W., Hadj Hassine, A. I., Bouaziz, A., Bartegi, A., Thomas, O., \& Roig, B. (2011). Effect of endocrine disruptor pesticides: A review. International Journal of Environmental Research and Public Health, 8(6), 2265-2233.

Orton, F., \& Tyler, C. R. (2014). Do hormone-modulating chemicals impact on reproduction and development of wild amphibians? Biological Reviews of the Cambridge Philosophical Society, 90(4), 1100-1017.

Parsons, K. C., Mineau, P., \& Renfrew, R. B. (2016). Effects of pesticide use in rice fields on birds. Waterbirds, 33(1), 193218.

Paunescu, A., Ponepal, C. M., Drghici, O., \& Marinescu, A. G. (2010). Liver histopathologic alterations in the frog Rana (Pelophylax) ridibunda induce by the action of Reldan 40EC insecticide. Anale Universitatii Din Oradea, Fascicula Biologie, 17(1), 166-169.

Peltzer, P. M., Attademo, M. S., Lajmanovich, R. C., Junges, C. M., Beltzer, A. H., \& Sánchez, L. C. (2010). Trophic dynamics of three sympatric anuran species in a soybean agroecosystem from Santa Fe Province, Argentina. Herpetological Journal, 20(4), 261-269.

Pérez Iglesias, J. M., Franco-Belussi, L., Moreno, L., Tripole, S., De Oliveira, C., \& Natale, G. S. (2016). Effects of glyphosate on hepatic tissue evaluating melanomacrophages and erythrocytes responses in Neotropical anuran Leptodactylus latinasus. Environmental Science and Pollution Research, 23(10), 9852-9861.

Pérez Iglesias, J. M., Franco-Belussi, L., Natale, G. L., \& De Oliveira, C. (2019). Biomarkers at different levels of organization after atrazine formulation (SIPTRAN 500SC®) exposure in Rhinella schneideri (Anura: Bufonidae) Neotropical tadpoles. Environmental Pollution, 244, 733-746.

Piprek, R. P., Kloc, M., \& Kubiak, J. Z. (2014). Bidder's organstructure, development and function. The International Journal of Developmental Biology, 58, 819-827.

Power, R. P., \& Jetz, W. (2019). Global habitat loss and extinction risk of terrestrial vertebrates under future land-use-change scenarios. Nature Climate Change. https://doi.org/10.1038 /s41558-019-0406-z.

Pyron, A. R. (2018). Global amphibian declines have winners and losers. Proceedings of the National Academy of Sciences of the United States of America, 115(15), 3739-3741.

Quayle, W. C., Oliver, D. P., \& Zrna, S. (2006). Field dissipation and environmental hazard assessment to clomazone, molinate and thiobencarb in Australian rice culture. Journal of Agricultural and Food Chemistry, 54(19), 7213-7220.

Relyea, R. A. (2005). The lethal impact of Roundup on aquatic and terrestrial amphibians. Ecological Applications, 15(4), $1118-1124$.

Relyea, R. A., \& Jones, D. K. (2009). The toxicity of roundup original MAX® to 13 species of larval amphibians. Environmental Toxicology and Chemistry, 28, 2004-2008.

Rojas-Hucks, S., Gutleb, A. C., González, A. C., Contal, S., Mehennaoui, K., Jacobs, A., Witters, H., \& Pulgar, J. (2019). Xenophus laevis as bioindicator of endocrine disruptors in the region of central Chile. Archives of Enviromental Contamination and Toxicology, 77(3), 390408.
Rossi, A. S., Fantón, N., Michlig, M. P., Repetti, M. R., \& Cazenave, J. (2020). Fish inhabiting rice fields: Bioaccumulation, oxidative stress and neurotoxic effects after pesticides application. Ecological Indicators, 113, 106186.

Sánchez, L. C. (2011). Alteraciones de la dinámica y biología reproductiva de anuros (Amphibia, Anura) producidos por el avance de la frontera agrícola en ambientes naturales del Delta Superior del Rio Paraná. Tesis doctoral para optar el título de Doctor en Ciencias Biológicas. Universidad Nacional del Litoral. Facultad de Bioquímica y Ciencias Biológicas

Sánchez, L. C., Lajmanovich, R. C., Peltzer, P. M., Manzano, A. S., Junges, C. M., \& Attademo, A. M. (2014). First evidence of the effects of agricultural activities on gonadal form and function of Rhinella fernandezae and Dendropsophus sanborni (Amphibia: Anura) from Entre Rios, Province, Argentina. Acta Herpetológica, 9(1), 75-88.

Sánchez-Hernandez, J. (2020). Reciprocal role of salamanders in aquatic energy flow pathways. Diversity, 12(1), 32.

Sayed, A. H., \& Younes, H. A. M. (2017). Melanomacrophage centers in Clarias gariepinus as an immunological biomarker for toxicity of silver nanoparticles. Journal of Microscopy and Ultrastructure, 5(2), 97-104.

Scaia, M. F., Regueira, E., Sassone, A. G., \& Volonteri, M. C. (2011). The Bidder's organ of the toad Rhinella arenarum (Amphibia, Anura). Presence of steroidogenic enzymes. Journal of Experimental Zoology, 31, 439-446.

Sievers, M., Hale, R., Parris, K. M., Melvin, S. D., Lanctot, C. M., \& Swearer, S. R. (2019). Contaminant-induced behavioral changes in amphibians: A meta-analysis. Science of the Total Environment, 693, 133570.

SIIA. (2019). Sistema Integrado de Información Agropecuaria, Ministerio de Agricultura, Ganadería y Pesca de la Nación Argentina. http://www.siia.gov.ar/. Accesed 20 December 2019

Skelly, D. K., Bolden, S. R., \& Dion, K. B. (2010). Intersex frogs concentrated in suburban and urban landscapes. EcoHealth, 7, 374-379.

Smith, E. E., Du Preez, L. H., Gentles, A., Solomon, K. R., Tandler, B., Carr, J. A., et al. (2005). Assessment of laryngeal muscle and testicular cell types in Xenopus laevis (Anura Pipidae) inhabiting maize and nonmaize growing areas of South Africa. African Journal of Herpetology, 54(1), 69-76.

Spolyarich, N., Hyne, R. V., Scott, P. W., Palmer, C. G., \& Byrne, M. (2011). Morphological abnormalities in frogs from a ricegrowing región in NSW, Australia, with investigations into pesticide exposure. Environmental Monioring andt Assessment, 173, 397-407.

Steinel, N. C., \& Bolnick, D. I. (2017). Melanomacrophage centers as a histological indicator of immune function in fish and other poikilotherms. Frontiers in Immunology, 8, 827.

Tamschick, S., Rozenblut-Kościsty, B., Ogielska, M., Lehmann, A., Lymberakis, P., Hoffmann, F., Lutz, I., Kloas, W., \& Stock, M. (2016). Sex reversal assessments reveal different vulnerability to endocrine disruption between deeply diverged anuran lineages. Scientific Reports, 6, 23825.

Tavera-Mendoza, L., Ruby, S., Brousseau, P., Fournier, M., Cyr, D., \& Marcogliese, D. (2002). Response of the amphibian tadpole (Xenopus laevis) to atrazine during sexual 
differentiation of the testis. Environmental Toxicology and Chemistry, 21(3), 527-531.

Terrado, M., Küster, M., Raldua, D., López de Alda, M., Barcelo, D., \& Tauler, R. (2007). Use of chemometric and geostatistical methods to evaluate pesticide pollution in the irrigation and drainage channels of the Ebro river delta during the rice-growing season. Analytical and Bioanalytical Chemistry, 387(4), 1479-1488.

Trudeau, V. L., Thomson, P., Zhang, W. S., Reynaud, S., NavarroMartin, L., \& Langlois, V. S. (2020). Agrochemicals disrupt multiple endocrine axes in amphibians. Molecular and Cellular Endocrinology. https://doi.org/10.1016/j. mce.2020.110861.

Tsai, P. S., Kessler, A. E., Jones, J. T., \& Wahr, K. B. (2005). Alteration of the hypothalamic-pituitary-gonadal axis in estrogenand androgen-treated adult male leopard frog, Rana pipiens. Reproductive Biology and Endocrinology, 3, 2.

Vaira, M., Akmentis, M., Attademo, M., Baldo, D., Barraso, D., Barrionuevo, S., et al. (2012). Categorización del estado de conservación de los anfibios de la República Argentina. Cuadernos de Herpetología, 26(1), 131-159.

Vizgarra, C. G. (2018). Aplicación de agroquímicos en las localidades de Las Palmas y La Leonesa, Provincia del Chaco. Efectos en la salud de la población. (Trabajo final integrador). Bernal, Argentina. Universidad Nacional de Quilmes. https://ridaa.unq.edu.ar/handle/20.500.11807/849

Zar, J. H. (1999). Biostatistical Analysis (4th ed.). Prentice Hall. Zaracho, V. H., Céspedez, J. A.; Álvarez, B. B., Lavilla, E. O. (2011). Anfibios de Corrientes. Guía de campo para la identificación de los Anfibios de la provincia de Corrientes (Argentina). Fundación Miguel Lillo, Ministerio de Educación de la Nación

Zhelev, Z. M., Popgeorgiev, G. S., \& Mehterov, N. H. (2015). Changes in the hepatosomatic index and condition factor in the populations of Pelophylax ridibundus (Amphibia: Ranidae) from anthropogenically polluted biotopes in Southern Bulgaria. Part II. Bulgarian Journal of Agricultural Science, 21(3), 534-539.

Zhelev, Z. M., Tsonev, S. V., \& Arnaudova, D. N. (2017). Health status of Pelophylax ridibundus (Pallas, 1771) (Amphibia: Ranidae) in rice paddy ecosystem in Southern Bulgaria: Body condition factor and fluctuating asymmetry. Acta Zoologica Bulgarica, 69(8), 169-176.

Zieri, R., Franco-Belussi, L., De Souza Santos, L. R., Taboga, S. R., \& De Oliveira, C. (2015). Sex hormones change visceral pigmentación in Eupemphix nattereri (Anura): Effects in testicular melanocytes and hepatic melanomacrophages. Animal Biology, 62, 21-32.

Zimmerman, B. L. (2001). Transectas de bandas auditivas. In W. R. Heyer, M. A. Donolly, R. W. McDiarmid, C. Hayek, \& M. S. Foster (Eds.), Medición y monitoreo de la diversidad biológica, Métodos estandarizados para anfibios (pp. 87-93). Editorial universitaria de la Patagonia.

Publisher's Note Springer Nature remains neutral with regard to jurisdictional claims in published maps and institutional affiliations. 